\title{
Using Multimedia Interactive in Online Learning in the Covid-19 Pandemic
}

\author{
Dariyono \\ School of Postgraduate Studies \\ Universitas Pendidikan Indonesia \\ Bandung, Indonesia \\ dariyono.mas@upi.edu
}

\author{
Mukhidin* \\ Faculty of Technology and Vocational Education \\ Universitas Pendidikan Indonesia \\ Bandung, Indonesia \\ *mukhidin@upi.edu
}

\begin{abstract}
The Covid-19 outbreak has changed learning patterns that have been carried out by face-to-face methods with online learning. The purpose of this study was to find alternative learning methods implemented during the pandemic. The method used was a literature review. Online learning with computer-based interactive multimedia such as drills, tutorials, simulations, and games, can comply with health protocols. These learning methods can be used when the teacher and students are far apart, communication can be carried out effectively. The implication of this learning method is that students are increasingly creative, teachers are required to learn information technology. In addition, students are required to be independent, using various learning sources. The results of this study can be used for elementary school to senior high school education.
\end{abstract}

Keywords - interactive multimedia, online learning

\section{INTRODUCTION}

Advances in information and communication technology that occur at this time have a significant impact on learning activities. the use of computer and internet technology devices is an inevitable part of the learning process in the current era. Teachers are required to have the ability to use technological devices to support the learning process even more so with the presence of the Corona Virus Disease (Covid-19) outbreak in more than 200 countries encouraging governments to issue social policies instancing to large-scale social restrictions which resulting in school learning activities should be carried out by distance learning or online mode respectively by utilizing technological devices and internet networks.

Policy work from home as well as social distancing changes in habitual patterns of learning in education. Pandemic COVID-19 has created a major change to the learning process at school, from initially learning done face-to-face in the classroom now learning is done online through technological devices using both computers and smartphones connected to the internet network. Faced with these conditions, teachers are required to adapt and should accelerate in the use of technological devices to carry out online learning.
The transition from face-to-face learning to online models certainly has a shock effect on all parties. In general online learning can be defined as an education system that provides information using information technology resources such as the internet, intranet, satellite broadcasts, and multimedia applications. Teachers who are technology illiterate will find it difficult to carry out online learning. Online learning to be effective it is necessary for the selection of methods and strategies in presenting the material of learning. One learning strategy that can be pursued by teachers in implementing online learning is by using interactive multimedia. Because interactive multimedia can facilitate students with a variety of learning styles (auditory, visual, kinesthetic). Besides, the use of multimedia is more effective because it can present information that can be seen, heard, and done. Results of research conducted Mukhidin [1] that based learning interactive multimedia can improve results Learning and independent students' most important discovery in his research, multimedia interactive able to improve the competence of students in the cognitive, improve the competence of students in cognitive, improving ability to work together in study groups, train creative thinking, and communicate, and be able to apply various abilities skillfully when working on student worksheets. Then in research conducted by Computer Technology Research (CTR), the results state that people are only able to remember $20 \%$ of what was seen and $30 \%$ of what was heard. But people can remember $50 \%$ of what is seen and heard and $80 \%$ of what is seen, heard, and done at the same time [2]. Therefore, utilizing multimedia in the learning process is considered necessary because it can improve student memories. This paper will discuss about the use of interactive multimedia in online learning in the middle of pandemic. Based on the description above, the focus of discussion in this paper is the use of interactive multimedia media on primary school online learning in the middle of the pandemic Covid-19.

\section{METHOD}

This study used a literature review for gathering information and data from various resources such as 
documents, books, magazines, historical stories, etc. [3]. A literature review can also learn reference books, as well as the results of previous studies of a similar type, are useful to get the theoretical basis of the problem to be in the review [4]. The literature for references was taken from reputable international journals available on google scholar, science direct then sorted from research articles, books, magazines. Furthermore, a selection was carried out so that it fits the problem under study and the focus of the research. References was focused on the findings of research on online learning and learning during a pandemic. Then the collection of literature related to various learning media with interactive multimedia, to be analyzed follows the literature review method procedure.

\section{RESULTS AND DISCUSSION}

\section{A. Online Learning}

Learning online is a distance learning that an insane by utilizing technological devices and network Internet in the learning process. Learning online has the characteristic learners to construct and create knowledge independently, build knowledge, learners must be able to collaborate to solve problems, and establish inclusive learning community. Online learning is also carried out with virtual classes [5]. Online learning models have provided new experiences that are more challenging than face-to-face learning models [6], because teachers must manage learning in virtual classrooms where interaction does not occur directly. In the implementation of online learning is still found some obstacles such as network conditions are not stable, some many teachers and students are not familiar in using the various $\mathrm{f}$ a site learning online system [7].

\section{B. Multimedia Interactive}

In language, the word multimedia consists of two words, multi, which means a lot and a medium that means an intermediary. Vaughan says that multimedia is a combination of text, art, sound, animation, and video delivered through computers or electronic and digital equipment [8]. Based on this opinion, it can be interpreted that multimedia is a combination of several kinds of media that are useful for learning. Learning with Multimedia is learning to use the computer to combine information such as text, images, sound, animation, or even video to be shown to the learners. There are two types of multimedia, namely linear multimedia (fixed) and interactive multimedia (can be controlled).

According Ariesto Hadi Sutopo argues that interactive multimedia is multimedia equipped with a controller that can be operated by the user so that the user can choose what you desire for the next process, ask questions, and get answers that affect a computer to perform the functions hereinafter [9]. Interactive multimedia plays a big role in teaching and learning activities in schools. one of the objectives of learning with interactive multimedia is wherever possible replace or complement and support the following elements: objectives, materials, methods, and assessment tools in the teaching and learning process in the conventional education system we used to do. The forms of utilizing computer-based interactive multimedia models in learning can be in the form of drills, tutorials, simulations, and games [10].

1) Drills model: Drills model is a form of computer-based interactive learning model (CBI) which aims to provide a more concrete learning experience through the provision of exercises to test student performance through the speed of completing the given question exercises [11]. This drill model is used to train students to use concepts, rules, or procedures that have been previously taught. Through a series of examples of concepts and knowledge learned, students are allowed to practice to be skilled in applying the concepts and knowledge. For this reason, the drill program model should be equipped with the correct answers and their explanations so that it is hoped that students will also be able to understand a particular concept. In the final section, students can see the final score that he achieved as an indicator to measure the level of success in solving the questions proposed. Through the drills model, certain habits will be instilled in the form of exercise. With continuous practice, this model is intended to train students so that they have skills in a skill or strengthen the mastery of a concept. The purpose of learning through the drill and practice model basically provides the conditions of the exercise (exercise) and recall (recall) about the information from the learning material or certain information within a specified time.

The drill model provides a set of questions or questions that are usually displayed randomly, so that every time they are used, the questions or questions that appear are always different, or at least in different combinations, it will be embedded and then it will become a habit. In addition to instilling habits, this model can also add speed, determination, perfection in doing something and can also be used as a way to repeat the material that has been presented.

The important thing to note in order to take advantage of this model is the continuous rewards. Rewards are given each time a student successfully does his assignment well. Giving a positive reward will provide a greater possibility for students to repeat the success that has been achieved. This is known as reinforcement or confirmation of learning outcomes. In general, the material stages of the drill model are as follows:

- Describe problems in the form of exercises on a certain level of student performance.

- Students doing practice exercises.

- The program records student performance, evaluates then provides feedback.

- If the answer given is correct the program presents the next problem and if the wrong answer progaram provides facilities to repeat the exercise or remediation, which can be given partially or at the end of the whole problem. 
2) Tutorial model: Tutorial model is an interactive learning program used in the teaching and learning process by using software or software in the form of computer programs containing subject matter. The tutorial model is designed to act as a tutor for students. This means that this model is presented in a dialogue format with students. The tutorial model contains concepts, explanations, formulas, principles, charts, tables, definitions, terms and exercises. The purpose of this interactive multimedia tutorial model is to provide "satisfaction" or a thorough understanding (mastery) to students about the material or subject matter being studied [11]. Students can be given the opportunity to choose learning topics that they want to learn in a subject. The more topics of learning that can be selected, will be more easily accepted by the students of the program. In a learning interaction in the form of a tutorial, information and knowledge are communicated in such a way as the situation at the time the teacher is giving instruction to students. Simply put the patterns of computer operation as an instructor on this tutorial model, namely:

- The computer presents the material.

- Students respond.

- Student responses are evaluated by computers with an orientation towards the students in following their next achievement.

- Continue or repeat the previous steps.

Tutorial in interactive multimedia learning program is intended as a substitute for the instructor as a human being he ngsung in fact, given the $\mathrm{k}$ 's in the form of text or graphics on the screen that have provided points questions or concerns.

3) Simulation method: The simulation model is one of learning strategies that aims to provide concrete experiences through the creation of imitations of experiences that approach the atmosphere of experience that approaches the real atmosphere and takes place in an atmosphere without risk. The purpose of learning through simulation models is oriented towards efforts in providing real experiences to students through imitation of the atmosphere. Simulation models are divided into four categories, namely: physical, situation, procedure, and process. In general, the material stages of the simulation model are as follows: introduction, presentation, information, (simulation 1, simulation 2, etc.), questions and response to responses, response assessment, giving feedback about responses, repetition, segment of teaching arrangements, and closing.

4) Instructional games model: The game model is a form of model that is designed to arouse excitement in students so that it can increase the possibility of storing longer concepts, knowledge or skills that they are expected to gain from the game. The purpose of the game model is to provide an atmosphere (environment) that provides learning facilities that increase students' abilities. Game models don't need to mimic reality but can have characters that provide fun challenges for students. The whole model of this game has a basic component as a motivational generator by bringing up the way to compete to achieve something. Interaction in the form of a game will be instructional if the knowledge and skills contained in it are academic and contain training elements. A form of play is called instructional if there are learning objectives to be achieved [2]. It must also be remembered that the form of the game presented still refers to the teachinglearning process and is computer-based. this model is expected to occur in learning activities while playing. Thus students do not feel that they are learning.

Benefits of multimedia for learning In general, the benefits that can be obtained are more interesting multimedia learning processes, more interactive, the amount of teaching time (lectures) can be reduced, the quality of student learning can be more motivated and boosted, teaching and learning can be done anywhere and anytime (very flexible), and the attitudes and concerns of student learning can be improved and centered.

Interactive Multimedia in Learning has the characteristics of: Combining elements between audio and visual; $\mathrm{Be}$ interactive and can accommodate user responses; $\mathrm{Be}$ independent, provide convenience and completeness of the content so that users can use without guidance from the teacher. The ability and ability to use interactive multimedia in learning, namely:

- Provides interactive processes and provides easy feedback.

- Give freedom to students in determining the topic of the learning process.

- Providing the ease of systematic control in the learning process.

- The learning system will be more innovative and interactive.

- Teachers will always be required to be creative in finding innovative breakthroughs in learning.

\section{CONCLUSION}

In implementing online learning teachers are required to have the ability to use and utilize technology and internet devices. Teachers must be creative and innovative in designing and implementing online learning. One strategy in implementing online learning is to use multimedia interactive such as driil model, tutorial, simulation, and instructional games model. 


\section{REFERENCES}

[1] Mukhidin, Pengembangan Kurikulum Pendidikan Teknoogi Agroindustri Berbasis Kerangka Kualifikasi Nasional Indonesia proceedingfptk, 438, 2015.

[2] Munir, Distance Learning Based on Information and Communication Technology. Bandung: Alfabeta, 2009.

[3] Mardalis, Metode Penelitian Suatu Pendekatan Proposal. Jakarta: Bumi Aksara, 1999.

[4] S. Jonathan, Quantitative and Qualitative Research Methods. Yogyakarta: Graha Science, 2006.

[5] Directorate General of Ministry of Education and Culture GTK National Instructor Training Handbook / Learner Teacher Mentor. Jakarta, 2016
[6] H.U. Ummi and I. Mulyaningsih, "Journal of Indonesian Language Education and Literature," Journal of Indonesian Language Education and Literature, vol. 3, no. 1, pp. 53-65, 2017.

[7] D. Jamaluddin, T. Ratnasih, H. Gunawan and E. Paujiah, "Covid-19 Pandemic Period Online Learning in Prospective Teachers: Obstacles, Solutions and Projections," UIN Sunan Gunung Djjati Bandung Scientific Papers, pp. 1-10, 2020.

[8] T. Vaughan, Multimedia: Making it work. Tata McGraw-Hill Education, 2006.

[9] A.H. Sutopo, Interactive Multimedia with Flash. Yogyakarta: Graha Science, 2003

[10] Rusman, Computer Based Interactive Multimedia Models, P3MP, UPI, 2005 .

[11] M.A. Erik, The Effectiveness of Improving Learning Outcomes By Using Interactive Multimedia Model Drill And Practice in ICT Learning, 2009. 